\title{
The use of selected regranulates in silicate masonry elements
}

\author{
Milena Nowek \\ Kielce University of Technology, al. 1000-lecia PP 7, 25-314 Kielce, Poland
}

\begin{abstract}
The paper describes the proposal of modification of sand-lime masonry elements with selected polymers in the form of regranulate and regrind. Such modification has two beneficial effects. Firstly, silicate products with mentioned additives are characterized by better functional properties, i.a. compressive strength, bulk density and water absorption. On the other hand, it gives the new opportunities for waste management and brings environmentally friendly and durable construction material. The results of research performed on the modified sand-lime products are presented and compared with the properties of the traditional silicate elements. The impact of introduced polymers on the microstructure and elemental structure of resulting products is briefly featured.
\end{abstract}

Keywords: sand-lime products; recycled polymers; waste managemen; environmentally friendly materials.

\section{Introduction}

Silicates are known as the healthiest building material. All sand-lime products are a replica of a sandstone - the rock constituting an element of the earth's crust. The production technology of sand-lime bricks is a mapping of a sandstone formation in natural conditions. Manufacturing technology of the "artificial sandstone" was invented and patented by German scientist Wilhelm Michalelis in 1880. On an industrial scale the technology was first used in 1894. Sand-lime brick is known, therefore, for more than 100 years. In Western Europe silicate brick has long been widely used and highly valued building material. In Germany, Netherlands and Scandinavian countries about 40-60 percent of walls in residential buildings is made of sand-lime bricks or blocks.

The manufacturing process of traditional silicates uses only natural materials and the production process itself is environmentally neutral and energy efficient. After mixing about $90 \%$ of sand and $7 \%$ of lime with the addition of $3 \%$ of water, the materials remain several hours in steel silos and are thoroughly mixed. Then the sand-lime mixture goes to press, in which is formed into bricks or blocks of appropriate size and shape. In the last stage the compressed elements are finally formed in autoclaves during from 6 to 12 hours (depending on size) of recrystallization, by the action of water vapor at approx. 200 degrees Celsius, under a pressure of 1.6 MPa.

Thanks to the process of autoclaving, sand-lime products have very good functional properties. With silicate bricks and blocks multi-storey buildings can be erected. Apart from high compressive strength, silicates are durable and frost resistant material. They are characterized by good acoustic insulation and dimensional accuracy. They are also cheaper than traditional ceramic brick.

In order to improve certain characteristics of silicate products (compressive strength, water absorption and bulk density) studies on silicates modified by addition of selected polymers were performed. However, due to ecological aspect, it was decided to use recycled additives.

Plastics are materials that can be found almost everywhere around us. They successfully replace traditional raw materials such as wood, metal and glass, and in many applications do not have a natural equivalent. Plastics, that is to say polymers, are large and long molecules made up of smaller ones, called monomers. Polymers are mostly materials inert to health and the environment, in contrast to the monomers, from which they arise. Confusing the properties of the monomers and polymers is the source of many misunderstandings and incorrect opinions on the plastics.

The polymers may be natural or synthetic. Natural polymers are commonly found in the world of plants and animals. Synthetic polymers for the most part are produced from crude oil, wherein only 4 percent of global extraction is converted into plastics. Although plastics represent only 1 percent of the mass of waste produced by us, however, are important when

Corresponding author: Milena Nowek. E-mail address: milena.nowek@gmail.com

http://dx.doi.org/10.3846/enviro.2014.041

(C) 2014 The Author. Published by VGTU Press. This is an open-access article distributed under the terms of the Creative Commons Attribution License, which permits unrestricted use, distribution, and reproduction in any medium, provided the original author and source are credited. 
it comes to the impact on the environment. Due to its chemical structure do not decompose under natural conditions, therefore the storage of this material in a landfill should be avoided. Especially because plastics are a valuable material that can be recovered in various recycling processes.

Products from recycled plastics are widely available in the construction market. Recycled PCW profiles (which is the most popular plastic applied in construction) are willingly used, as well as gutters, pipes and lawn grates of reclaimed materials. An interesting thing is insulation made of recycled PET bottles. It arises from the milled packages glued together with a special adhesive and then compressed into slabs. The resulting material has properties comparable to that of polystyrene but is more durable. Of this material are manufactured drainage boards. It is also recommended as a stay-inplace framework, thermal insulation and a layer of inverted roofs. Thermal conductivity coefficient of dry slab is equal to $0.065 \mathrm{~W} / \mathrm{mK}$. Recycled plastics have also appeared in finishing materials, such as carpeting with fiber formed in $100 \%$ of receipt and recycling of old floor covering, additionally mounted to the substrate in a way that minimizes the use of adhesive that emits harmful volatile organic compounds. For the external flooring tend to be offered surfaces of rubber granules from recycled tires, similar to those that are successfully used on sports fields and children playgrounds.

\section{Conducted research}

The attempts to modification the sand-lime products with polymers are already known. Introduction of LDPE regranules to the silicate mixture resulted in a decrease in water absorption but also contributed to a decrease in compressive strength of resulting product [1].

As an additive used in the studies described in this paper applied was regranulate and regrind of high impact polystyrene (HIPS) and mix of polypropylene and polyethylene regrind ( $\mathrm{PP}+\mathrm{PE})$.

HIPS is a lightweight material with high stiffness, impact and crack resistant. Polystyrene HIPS contains caoutchouc bound physically or chemically. Accordingly to the share of the caoutchouc physical and mechanical properties of the material change. Products made of polystyrene HIPS are used among others to make equipment cases, elements of lighting fixtures and in the food industry to manufacture of packaging.

Polypropylene has a very low water absorbency and permeability. It is characterized by a low density, high corrosion resistance and relatively high surface hardness. It is a thermoplastic material and is suitable for injection molding and extrusion and to the production of foils and fibers. Polypropylene products retain the shape to a temperature of $150{ }^{\circ} \mathrm{C}$. Its properties depend largely on the molecular weight, the degree of polydispersity, the tacticity and crystallinity.

Polyethylene minimally absorbs moisture, has low density compared to other materials and high impact strength even at low temperatures. Its low weight and excellent insulation properties preferred polyethylene for use as a raw material in the manufacture of submarine cable under the English Channel. During World War II was used for the construction of lightweight aircraft radars. Today polyethylene is a popular material used in the production of many everyday items, household products, insulation materials or foils [2].

Samples with a content of 10, 20 and $30 \%$ of HIPS as well as 10 and $20 \%$ of PP+PE regrind were prepared and subjected to the tests. Each test was conducted on 6 rectangular samples with dimension of $40 \times 40 \times 160 \mathrm{~mm}$. The results are presented as an arithmetic mean of all outcomes.

Modified silicate products were tested on a strength press, determined was also their bulk density and water absorption. The analysis of the microstructure was carried out by scanning electron microscopy.

\section{Obtained results}

\subsection{Bulk density}

Bulk density of the elements was determined mathematically by dividing the sample weight by its volume. The results presented in the chart below (Fig. 1) were averaged. Traditional sand-lime products are produced with bulk density with the range from 1200 to $1700 \mathrm{~kg} / \mathrm{m}^{3}$ [3].

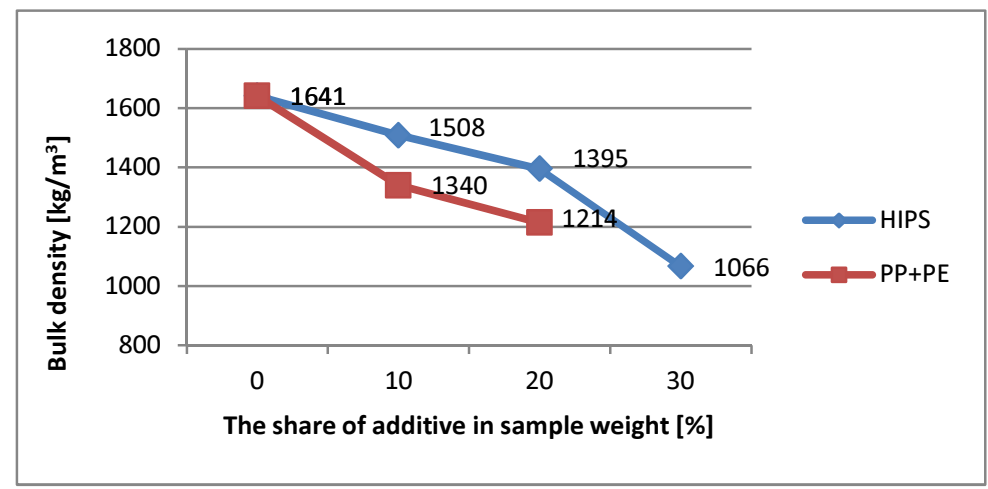

Fig. 1. Bulk density of modified silicate products 
The figure above shows the result of bulk density of modified silicate products depending on the amount of introduced additive. $\mathrm{PP}+\mathrm{PE}$ regrind contributed to a greater extent to decrease in bulk density of the samples compared to those with the addition of HIPS.

\subsection{Compressive strength}

All types of modified silicate samples meet the standard requirements for minimum compressive strength, which is equal to $5 \mathrm{MPa}$. The highest average compressive strength value obtained silicates with HIPS regranulate in an amount of $20 \%$. All compressive strength results are shown in the following chart.

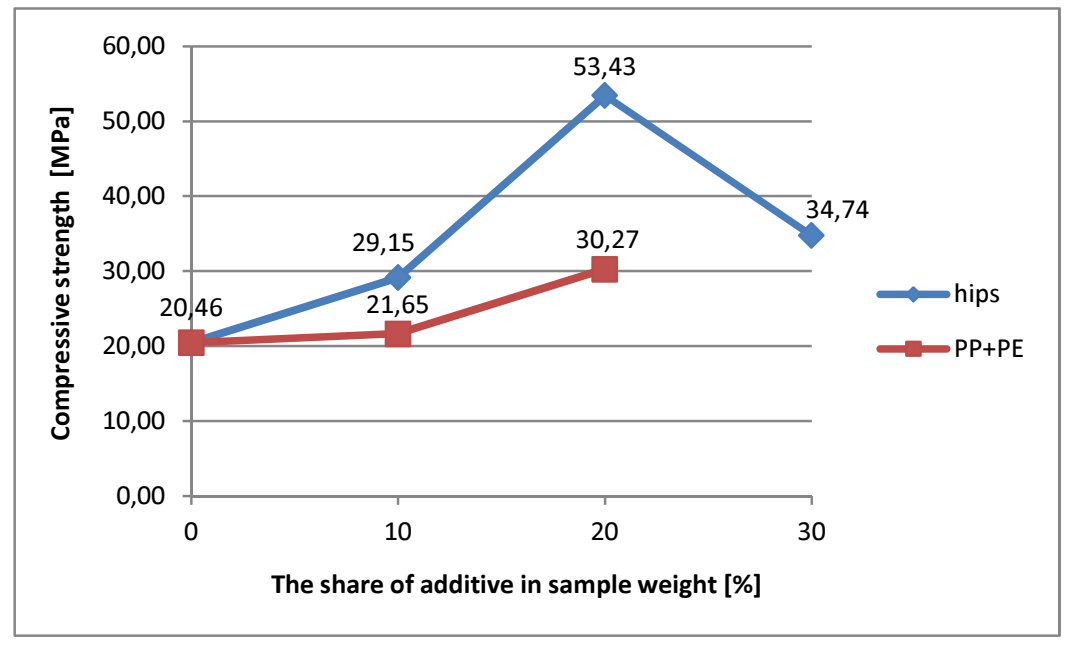

Fig. 2. Compressive strength of modified silicate products

\subsection{Water absorption}

The chart below shows the averaged results of water absorption of examined samples. All modified silicate products are characterized by clearly reduced water absorption in comparison to the comparative samples

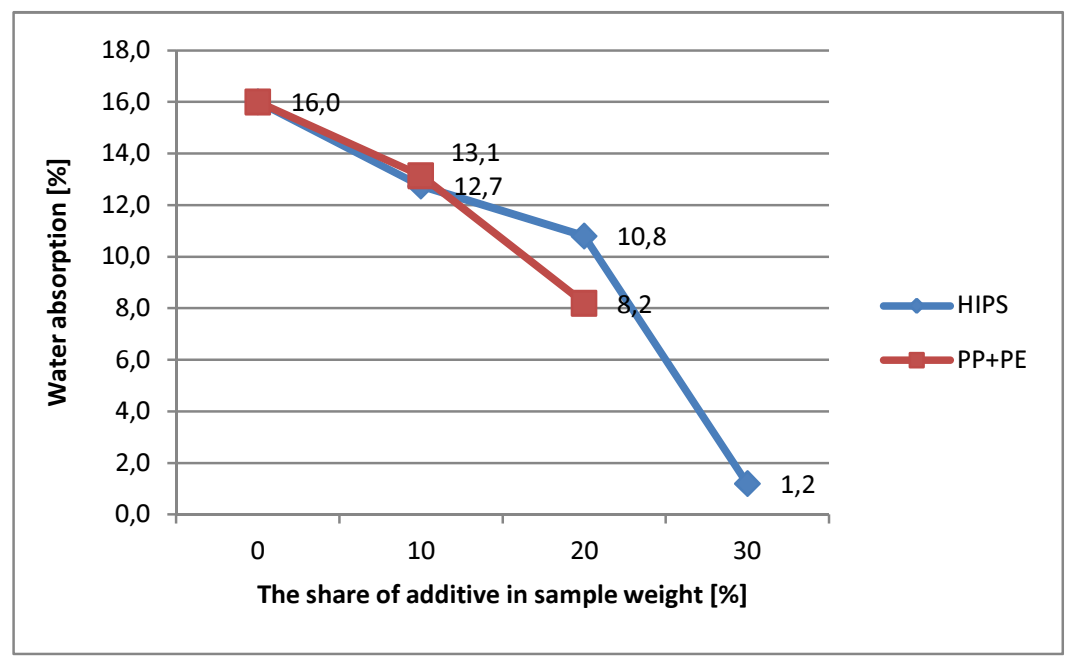

Fig. 3. Water absorption of modified silicate products

\subsection{Analysis of microstructure}

Silicates are obtained from a mixture of ground quartz sand and lime with a small amount of water. They emerge as a result of the hydrothermal treatment conducted under high pressure and at a specified temperature (app. $200{ }^{\circ} \mathrm{C}$ ). The high pressure causes strong bonds between silica and lime, resulting in a formation of calcium silicates $\mathrm{CaSiO}_{3}$ and then after the resulting chemical reaction gives the calcium carbonate $\mathrm{CaCO}_{3}$. In the chemical reaction lime binds with silicon dioxide $\mathrm{SiO}_{2}$, which is the main component of the sand used in silicate products.

$$
2 \mathrm{Ca}(\mathrm{OH})_{2}+\mathrm{SiO}_{2}=>2 \mathrm{CaO} \cdot \mathrm{SiO}_{2} \cdot 2 \mathrm{H}_{2} \mathrm{O}
$$

The manufacturing process of silicate products uses slaked lime. 
It was possible to interpret the structure of traditional silicate products thanks to the analysis performed by the use of the Scanning Electron Microscope. The interpretation revealed the existence of the C-S-H phase and the presence of the tobermorite. The C-S-H phase is a configuration of hydrated calcium silicates with a different level of structural arrangement: $\mathrm{CaO}-\mathrm{SiO}_{2}-\mathrm{H}_{2} \mathrm{O}$, which emerges as a result of the reaction between calcium silicates and water. The tobermorite is the most ideal form of the C-S-H phase. It is also a hydrated calcium silicate characterized by an arranged structure and specified inter-plane spaces $[4,5]$. The following pictures present the structure of the particular phases in a traditional silicate product.

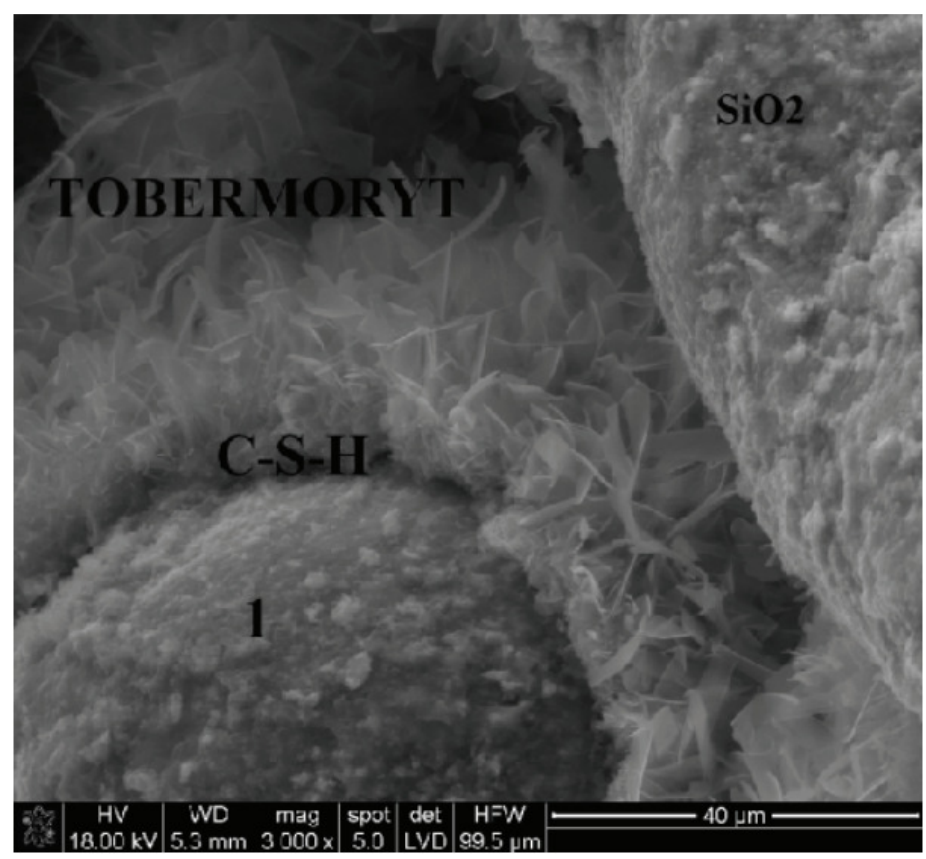

Fig. 4. The microstructure of traditional silicate product [7]

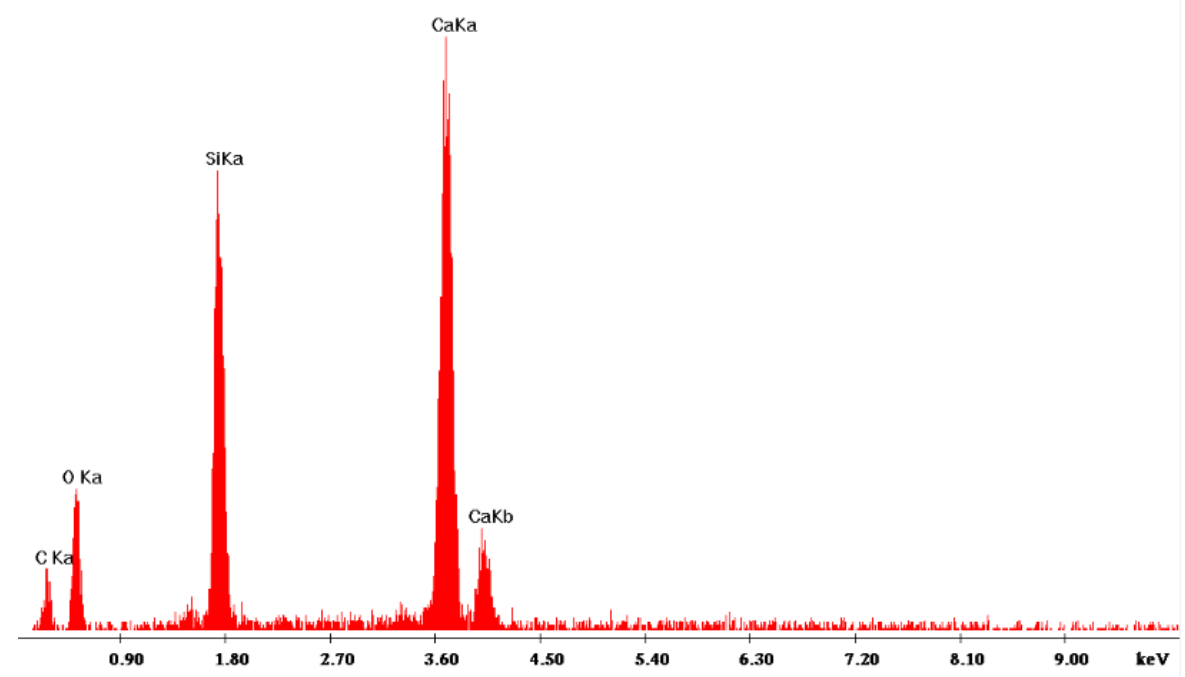

Fig. 5. Elemental structure of traditional silicate product

Figure 4 shows a sand grain surrounded by the C-S-H phase, which then transforms into a higher and more perfect form, i.e. tobermorite. The tobermorite phase in the traditional silicate product appears in the form of blades with flat endings. Figure 5 is a diphractogram presenting the elemental structure of traditional silicate product [4]. A small amount of carbon is a due to a preparation of test samples on the Scanning Electron Microscope.

The following pictures show the structure (Fig. 6) and elemental structure (Fig. 7) of the modified silicate products. 


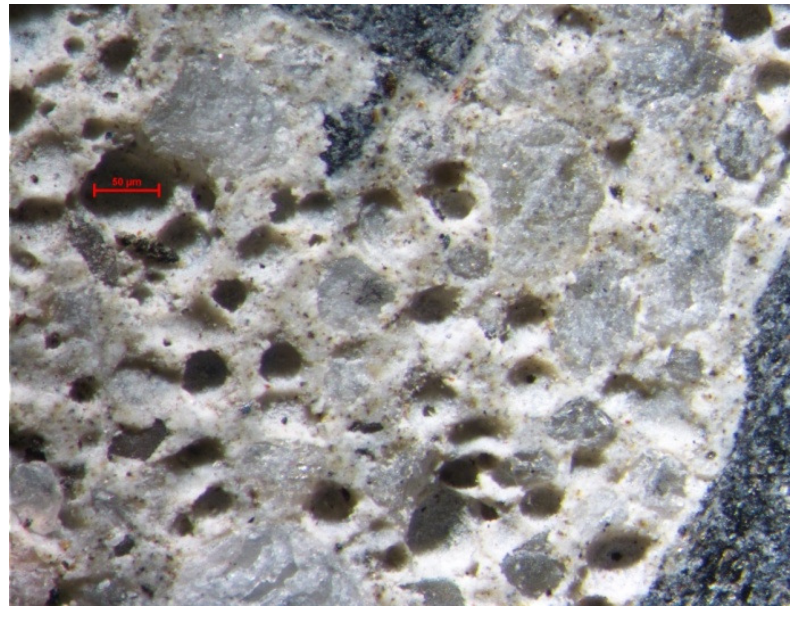

Fig. 6. The structure of the silicate product containing HIPS regranulate
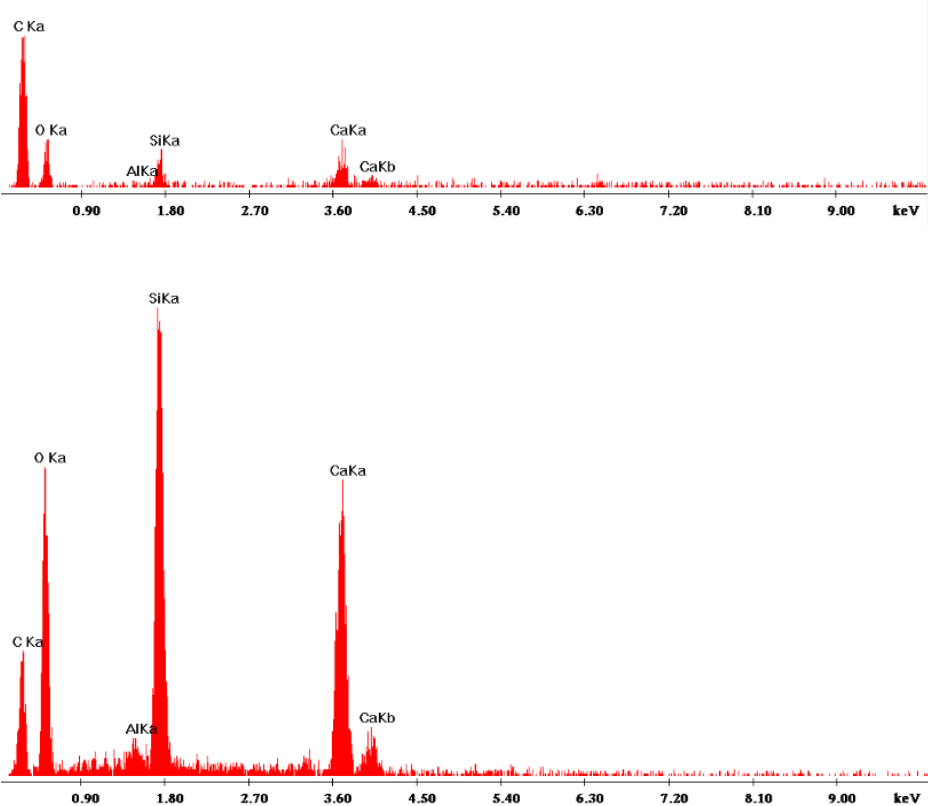

Fig. 7. Elemental structure of silicate product modified with HIPS

The diphractogram indicates, besides the elements found in a traditional silicate products, also a presence of carbon (from HIPS) and aluminum (introduced with the sand). High compressive strength of silicate product containing HIPS is a result of a good contact between the polymer and sand-lime mass ingredients.

Next pictures present the structure (Fig. 8) and elemental structure (Fig. 9) of modified sand-lime product with PP+PE regrind

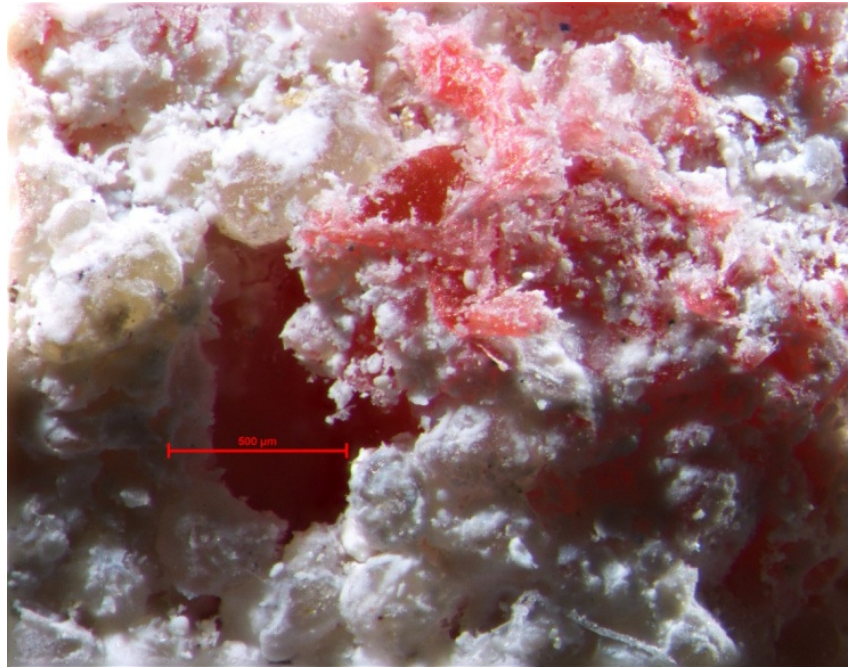

Fig. 8. The structure of modified silicate product containing $\mathrm{PP}+\mathrm{PE}$ regrind

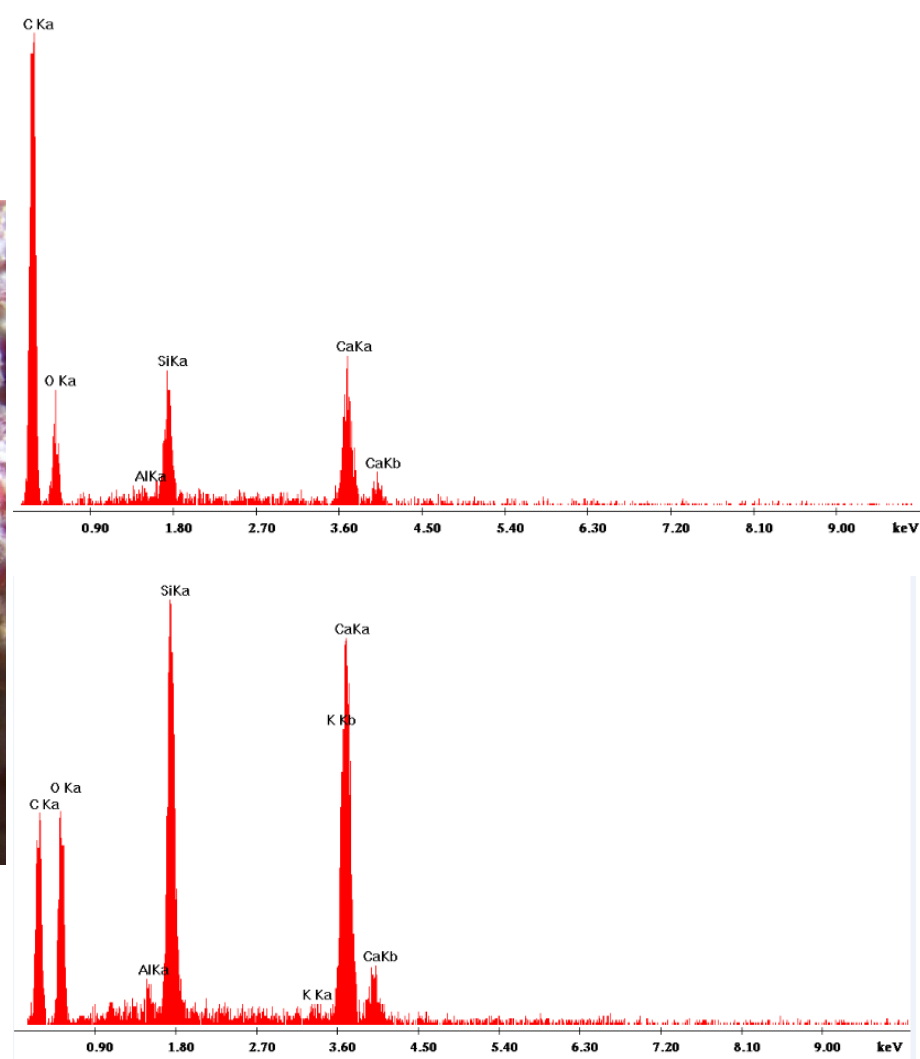

Fig. 9. Elemental structure of silicate product modified with $\mathrm{PP}+\mathrm{PE}$ regrind 
In the case of samples modified by addition of $\mathrm{PP}+\mathrm{PE}$ regrind the content of carbon has also grown. Like in the silicate with HIPS, polymer combines with the components of sand-lime mixture. Both in the sample with HIPS and that with $\mathrm{PP}+\mathrm{PE}$ noted was the presence of C-S-H phase and tobermorite.

\section{Conclusion}

As a result of conducted research can be concluded that the addition of recycled plastics to sand-lime products can help to improve their functional properties. Suitably chosen type of polymer and its amount influences the increase in compressive strength, decrease in bulk density and water absorption as well as changes in the microstructure of resulting product. Therefore, the use of plastic waste in silicate masonry elements seems to be beneficial. In addition to the advantage in the form of obtaining the material with improved properties, an important aspect is that such modified silicate product is environmentally friendly, because it contains additives from recycling of used equipment and everyday objects. This brings new opportunities to waste utilization of the ubiquitous polymers.

\section{References}

[1] Jasińska, I.; Nowek, M. 2013. Wpływ modyfikacji wyrobów silikatowych dodatkiem w postaci LDPE na ich podstawowe właściwości użytkowe, in Wybrane problemy naukowo-badawcze budownictwa i inżynierii środowiska, MDT Conference Płock 2013, p. 153-158.

[2] Pielichowski, J.; Puszyński, A. 2004. Chemia polimerów, Wyd. Naukowo-Techniczne Teza, Kraków.

[3] Jasiczak, J. 2005. Praca zbiorowa pod kierunkiem prof. dr.hab inż. Bogustawa Stefańczyka, Budownictwo Ogólne, Tom I Materiały i Wyroby Budowlane, Arkady, Warszawa.

[4] Dachowski, R.; Stępień, A. 2011. The impact of various additiveson the microsrtucture of silicate products, in Procedia Engineering 21: 1173-1178.

[5] Kurdowski, W. 2010. Chemia cementu i betonu. Warszawa, Wydawnictwo Naukowe PWN. 